\title{
Diversity in phenolic compounds, biochemical and pomological characteristics of Arbutus unedo fruits
}

\author{
Muttalip Gündoğdu ${ }^{1 *}$, Sezai Ercisli², Ihsan Canan ${ }^{1}$, Erdal Orman ${ }^{3}$, \\ Muhammad Sameeullah ${ }^{1}$,Muhammad Naeem ${ }^{4}$, Rayda Ben Ayed ${ }^{5}$
}

\author{
${ }^{1}$ Department of Horticulture \\ Faculty of Agriculture and Natural Sciences, Abant Izzet Baysal University, Bolu, Turkey \\ ${ }^{2}$ Department of Horticulture \\ Agricultural Faculty, Ataturk University, Erzurum, Turkey \\ ${ }^{3}$ Atatürk Horticultural Central Research Institute, Yalova, Turkey \\ ${ }^{4}$ Department of Plant Breeding \\ Genetics University College of Agriculture, ES The Islamia University, Bahawalpur, Pakistan \\ ${ }^{5}$ Centre of Biotechnology of Sfax, Sfax, Tunisia
}

\begin{abstract}
Strawberry trees (Arbutus unedo L.) are naturally grown in particular Black Sea and Mediterranean regions of Turkey with great diversity due to continuous seed propagation for centuries. The trees differ in terms of most of the horticultural characteristics. We investigated the phenolic compounds and the biochemical and pomological characteristics of the fruits of eight strawberry tree selections naturally grown in the western part of Turkey. Significant differences were found among the genotypes in terms of their phenolic compounds and

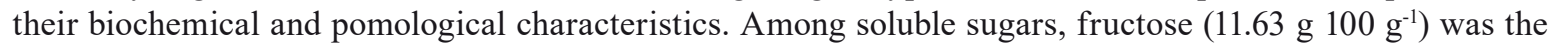

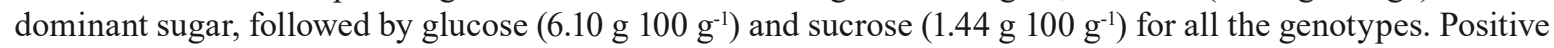
correlation was found between fruit weight and soluble sugar content. Malic acid was the major organic acid

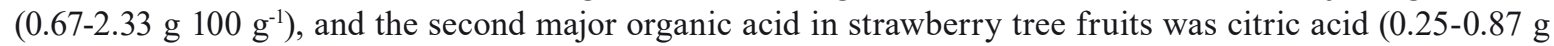

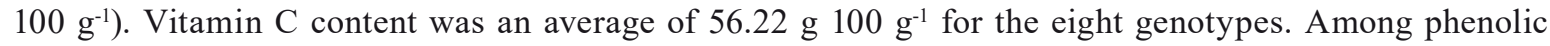
compounds, gallic acid was dominant (1.62-7.29 mg $\left.100 \mathrm{~g}^{-1}\right)$, followed by chlorogenic acid (1.23-3.14 mg $\left.100 \mathrm{~g}^{-1}\right)$, on an average basis.
\end{abstract}

Keywords: Arbutus unedo, organic acid, phenolics, sugar

\section{INTRODUCTION}

Turkey is regarded as one of the most important plant biodiversity centres in the world due to its geographical position, and the structure of its bioclimatic layers harbours a significant stock of plant genetic resources (Ercisli, 2004; Dogan et al., 2014; Alp et al., 2016; Canan et al., 2016). There are various neglected and underutilized fruit tree species grown in different parts of the world, and those fruit species could be exploited for use as foods, or used to obtain valuable natural compounds or derivatives (Kamiloglu et al., 2009; Tosun et al., 2009; Caliskan et al., 2012; Ercisli et al., 2012, Mikulic-Petkovsek et al., 2012, 2015; Veberic et al., 2015; Zorenc et al., 2016).

The strawberry tree (Arbutus unedo L.) belongs to the genus Arbutus and the family Ericaceae; it is

*Corresponding author. 
an evergreen fruit tree native to the Mediterranean area. The tree has the characteristics of a bushy shrub up to $3 \mathrm{~m}$ in height, but under favourable growth conditions it can reach a height of 9-12 m. This plant can grow at different altitudes, from sea level to $1200 \mathrm{~m}$, in various types of soils, but preferably acidic soils (Blanco et al., 1997). Fruits of this plant have been traditionally widely used for making marmalades along with fresh consumption in the Mediterranean region (Hadjichambis et al., 2008; Carvalho, 2010). The Arbutus fruit is a rich source of carbohydrates, organic acids, vitamin $\mathrm{C}$, phenolics, flavonoids and has great potential in terms of antioxidant capacities (Alarcao-E-Silva et al., 2001; Pallauf et al., 2008; Barros et al., 2010; Serçe et al., 2010; Ruiz-Rodríguez et al., 2011). Total antioxidant capacity of Arbutus fruits has been ranked fourth out of twenty-eight fruits, with a TEAC value of $163 \mu \mathrm{mol} \mathrm{g} \mathrm{g}^{-1}$, after persimmon, blackberry and blueberry (Garcia-Alonso et al., 2004). Therefore, the strawberry tree fruits promote health (Molina et al., 2011). In the past, a few studies were conducted to demonstrate the pomological characteristics and genetic diversity among Arbutus cultivars and genotypes from Turkey, Spain and a few other countries (Mulas et al., 1998; Celikel et al., 2008; Takrouni and Boussaid, 2010; Molina et al., 2011). This fruit tree is regarded as an endangered species, and even in Turkey its fruits are harvested in the wild and either consumed fresh or made into jams and other value-added products (Ayaz et al., 2000; Bonet and Vallès, 2002; Parada et al., 2002; Moll, 2005).

The aim of this study was to determine the phenolic compounds and the biochemical content and pomological properties of eight promising strawberry tree genotypes grown together in a single location. Based on these selection parameters, this will facilitate the breeding of new cultivars of strawberry tree fruits by incorporating the scattered desired traits from different genotypes into a single genotype.

\section{MATERIAL AND METHODS}

\section{Plant material}

Fruits of eight promising genotypes of Arbutus unedo, grown together at a single location in the Yalova province, were used in this study. Location of Yalova: $40^{\circ} 39^{\prime}$ North and $29^{\circ} 17^{\prime} \mathrm{E}$, at an altitude of $9 \mathrm{~m}$ above sea level. The fruits were harvested in both 2014 and 2015 at the commercially ripe stage. Random lots of fruits were established with
30 fruits each. From each genotype, approximately $500 \mathrm{~g}$ fruit samples were maintained at $-80^{\circ} \mathrm{C}$ until further analysis.

\section{Chemicals}

In this study, analytical grade chemicals were employed. Phenolic compound standards (gallic, catechin, chlorogenic, phloridzin, o-coumaric, $p$-coumaric, ferulic, vanillic, quercetin, rutin, ellagic, syringic and protocatechuic acid), organic acid standards (citric acid, malic acid, succinic acid, fumaric acid, and oxalic acid), vitamin C standards (L-ascorbic acid) and sugar standards (glucose, fructose, and sucrose) were obtained from SigmaAldrich (St. Louis, MO, USA).

\section{Extraction and determination of phenolic compounds}

The HPLC separation method was employed for the determination of phenolic compounds following the procedure described by Rodriguez-Delgado et al. (2001). Samples of about $100 \mathrm{~g}$ were minced and $5 \mathrm{~g}$ from each sample was transferred to centrifuge tubes. Each specimen was mixed uniformly and diluted with distilled water (1:1) and centrifuged at $15,000 \times \mathrm{g}$ for $15 \mathrm{~min}$. The supernatant was filtered through a $0.45 \mu \mathrm{m}$ membrane filter (Millipore Millex-HV Hydrophilic PVDF, Millipore, USA), then the filtrate was injected into the HPLC system (gradient). The separation of chromatographic data in an Agilent 1100 series HPLC took place in a DAD detector (Agilent, USA) with a $250 \mathrm{~mm}$ $\times 4.6 \mathrm{~mm}, 4 \mu \mathrm{m}$ ODS column (HiChrom, USA). The solvents used as mobile phase: Solvent A, methanolacetic acid-water (10:2:88) and Solvent B (Tab. 1), methanol-acetic acid-water (90:2:8); a flow rate of $1 \mathrm{dm}^{3} \mathrm{~min}^{-1}$ and $20 \mu \mathrm{L}$ injection volume were used for spectral determination at 254 and $280 \mathrm{~nm}$.

\section{Extraction and determination of organic acids}

For the extraction of organic acids, the procedure described by Bevilacqua and Califano (1989) was followed with modifications. $200 \mathrm{~g}$ samples

Table 1. The gradient elution program for the determination of phenolic compounds

\begin{tabular}{lcc}
\hline $\begin{array}{l}\text { Time } \\
(\text { min. })\end{array}$ & $\begin{array}{c}\text { Solvent A } \\
(\%)\end{array}$ & $\begin{array}{c}\text { Solvent B } \\
(\%)\end{array}$ \\
\hline 0 & 100 & 0 \\
15 & 85 & 15 \\
25 & 50 & 50 \\
35 & 15 & 85 \\
45 & 0 & 100 \\
\hline
\end{tabular}


were fragmented and $10 \mathrm{~g}$ from each sample was transferred to centrifuge tubes. The samples were mixed with $10 \mathrm{~mL}$ of $0.009 \mathrm{~N} \mathrm{H}_{2} \mathrm{SO}_{4}$ and then homogenized with a Heidolph Silent Crusher M, Germany. Thereafter, the samples were mixed by gentle shaking for an hour (Heidolph Unimax 1010 , Germany) and centrifuged at $14,000 \mathrm{rpm}$ for $15 \mathrm{~min}$. The supernatant was filtered through a coarse filter paper, then twice through a $0.45 \mu \mathrm{m}$ membrane filter (Millipore Millex-HV Hydrophilic PVDF, Millipore, USA), and finally in a SEP-PAK $\mathrm{C} 18$ cartridge. The concentrations of organic acids were determined by HPLC using an Aminex column (HPX-87H, $300 \mathrm{~mm} \times 7.8 \mathrm{~mm}$, Bio-Rad) fitted on an Agilent 1100 series HPLC G 1322 A, Germany) (Bevilacqua and Califano, 1989). Organic acids were determined at 210 and $250 \mathrm{~nm}$ wavelengths. $0.009 \mathrm{~N} \mathrm{H}_{2} \mathrm{SO}_{4}$ was used as the mobile phase.

\section{Extraction and determination of sugars}

The samples were prepared following the procedure described by Melgarejo et al. (2000) with small modifications. Briefly, a $10 \mathrm{~g}$ fruit sample was centrifuged at $12,000 \mathrm{rpm}$ for $2 \mathrm{~min}$. at $4^{\circ} \mathrm{C}$. Then the supernatant was filtered with a SEP-PAK C18 cartridge and transferred into a vial for analysis. The concentrations of sugars were determined by HPLC (isocratic program), with a $\mu$ Bondapak- $\mathrm{NH}_{2}$ column and a refractive index (RI) detector, and with $85 \%$ acetonitrile as the mobile phase. The quantification of the concentrations was based on standards.

\section{Determination of Trolox equivalent antioxidant capacity (TEAC)}

Trolox equivalent antioxidant capacity (TEAC) was determined with ABTS (2, 2'-azino-bis-3 -ethylbenzothiazoline-6-sulfonic acid) by dissolving in an acetate buffer using potassium persulphate (Ozgen et al., 2006). For longer stability, the mixture was diluted with $20 \mathrm{mM}$ sodium acetate buffer in an acidic $\mathrm{pH}$ of 4.5 , and read at $734 \mathrm{~nm}$ wavelength, $0.700 \pm 0.01$. For the spectrometric assay, $3 \mathrm{dm}^{-3}$ ABTS + was mixed with a $20 \mathrm{dm}^{-3}$ fruit extract sample and incubated for 10 min.; absorbance was detected at $734 \mathrm{~nm}$.

\section{Ascorbic acid (vitamin C) extraction and determination}

Ascorbic acid content was determined by a modified HPLC procedure (isocratic program) (Agilent 1100 series HPLC G 1322 A, Germany) as described by Cemeroglu (2007). A $5 \mathrm{~g}$ fruit sample was transferred to a $50 \mathrm{dm}^{-3}$ volumetric flask including
$10 \mathrm{dm}^{-3}$ of $6 \%(\mathrm{w} / \mathrm{v})$ metaphosphoric acid (Sigma, M6285, 33.5\%). The sample was homogenized at $24,000 \mathrm{rpm}$ for $15 \mathrm{~s}$, and then centrifuged at $14,000 \mathrm{rpm}$ for $10 \mathrm{~min}$. at $1^{\circ} \mathrm{C}$. The supernatant $\left(5 \mathrm{dm}^{-3}\right)$ was filtered through $0.45 \mu \mathrm{m}$ PTFE syringe filters (Phenomenex, UK) and placed in an ambercoloured vial (AIM, Screw vial, SV-15A). Ascorbic acid was quantified by an external standard method using an L-ascorbic acid standard (Sigma A5960). A Luna C18 column $(250 \mathrm{~mm} \times 4.60 \mathrm{~mm}, 5 \mu \mathrm{m}$ from Phenomenex) at $25^{\circ} \mathrm{C}$ was used for sample separation by HPLC. The mobile phase was $25 \mathrm{mM}$ $\mathrm{KH}_{2} \mathrm{PO}_{4}$ (adjusted to $\mathrm{pH} 2.2$ with phosphoric acid) with a flow rate of $1 \mathrm{dm}^{3} \mathrm{~min}^{-1}$. L-ascorbic acid was detected at $254 \mathrm{~nm}$.

\section{Some pomological properties and colour values}

A total of 30 fruits were sampled for traits such as fruit weight $(\mathrm{g})$, fruit length $(\mathrm{mm})$ and fruit width $(\mathrm{mm})$. The fruit colour was measured using a portable Minolta Chroma Meter (Minolta, Model CR-400), which provided CIE $L^{*}, a^{*}$ and $b^{*}$ values (McGuire, 1992).

\section{Statistical analysis}

In the present study, we used a total of 90 fruits per genotype, with 3 replicates including 30 fruits per replicate. The means were evaluated according to descriptive statistics represented as Mean \pm SE. Data were evaluated by using ANOVA, and significant differences among the means of three replicates $(p<0.005)$ were determined by Duncan's multiple range test using SPSS 20 for Windows.

\section{RESULTS AND DISCUSSION}

There were no statistical differences between the years, thus the data were pooled. Fruit weight was statistically significantly different among the genotypes $(p<0.05)$ (Tab. 2). The genotype 77YLV02 exhibited the highest fruit weight $(8.70 \mathrm{~g})$, and was followed by 77YLV06 (7.55 g), 77YLV04 (7.10 g) and 77YLV06 (6.90 g). Almost all the genotypes exhibited similar fruit length, ranging from 13.72 to $21.07 \mathrm{~mm}$. The width of fruit in 77YLV02 was $26.71 \mathrm{~mm}$, and this value was significantly higher than the values for all the rest of the genotypes, while the lowest fruit width was observed in 77YLV05 $(18.42 \mathrm{~mm})$. The pomological characteristics (fruit weight, length and width) presented in this study are comparable with those reported by Serçe et al. (2010), who utilized fruits of Arbutus unedo genotypes sampled from the 
Table 2. Some pomological properties and colour values of Arbutus unedo fruits (mean of 2014 and 2015)

\begin{tabular}{lcccccc}
\hline Genotypes & $\begin{array}{c}\text { Weight } \\
(\mathrm{g})\end{array}$ & $\begin{array}{c}\text { Length } \\
(\mathrm{mm})\end{array}$ & $\begin{array}{c}\text { Width } \\
(\mathrm{mm})\end{array}$ & $L$ & $a$ & $b$ \\
\hline 77 YLV 01 & $6.90 \pm 0.30 \mathrm{~b}^{*}$ & $19.41 \pm 0.20 \mathrm{a}$ & $23.92 \pm 0.83 \mathrm{bc}$ & $40.93 \pm 1.25 \mathrm{bc}$ & $43.92 \pm 0.69 \mathrm{ab}$ & $39.38 \pm 1.37 \mathrm{c}$ \\
77 YLV 02 & $8.70 \pm 0.10 \mathrm{a}$ & $21.07 \pm 1.01 \mathrm{a}$ & $26.71 \pm 1.70 \mathrm{a}$ & $35.50 \pm 1.50 \mathrm{~d}$ & $44.71 \pm 0.86 \mathrm{a}$ & $34.24 \pm 1.15 \mathrm{~d}$ \\
77 YLV 03 & $4.58 \pm 0.17 \mathrm{c}$ & $13.72 \pm 1.02 \mathrm{~b}$ & $20.33 \pm 1.03 \mathrm{de}$ & $42.21 \pm 0.45 \mathrm{~b}$ & $31.14 \pm 1.81 \mathrm{~d}$ & $43.70 \pm 1.87 \mathrm{~b}$ \\
77 YLV 04 & $7.10 \pm 0.20 \mathrm{~b}$ & $21.32 \pm 0.98 \mathrm{a}$ & $23.33 \pm 0.37 \mathrm{bc}$ & $41.61 \pm 1.30 \mathrm{bc}$ & $38.38 \pm 2.24 \mathrm{bc}$ & $43.59 \pm 1.87 \mathrm{~b}$ \\
77 YLV 05 & $4.85 \pm 0.15 \mathrm{c}$ & $19.77 \pm 0.51 \mathrm{a}$ & $18.42 \pm 0.61 \mathrm{e}$ & $46.03 \pm 1.06 \mathrm{a}$ & $32.16 \pm 2.91 \mathrm{~d}$ & $47.10 \pm 1.02 \mathrm{a}$ \\
77 YLV 06 & $7.55 \pm 0.45 \mathrm{~b}$ & $19.86 \pm 0.70 \mathrm{a}$ & $24.87 \pm 0.37 \mathrm{ab}$ & $40.06 \pm 0.85 \mathrm{c}$ & $43.24 \pm 1.95 \mathrm{ab}$ & $40.36 \pm 0.95 \mathrm{c}$ \\
77 YLV 07 & $5.65 \pm 0.51 \mathrm{c}$ & $18.53 \pm 0.78 \mathrm{a}$ & $23.30 \pm 1.87 \mathrm{bc}$ & $33.11 \pm 0.55 \mathrm{e}$ & $33.02 \pm 1.55 \mathrm{~cd}$ & $31.54 \pm 0.55 \mathrm{e}$ \\
77 YLV 08 & $4.70 \pm 0.50 \mathrm{c}$ & $17.25 \pm 0.69 \mathrm{ab}$ & $21.66 \pm 0.76 \mathrm{~cd}$ & $32.06 \pm 0.67 \mathrm{e}$ & $34.62 \pm 1.04 \mathrm{~cd}$ & $29.93 \pm 0.31 \mathrm{e}$ \\
\hline
\end{tabular}

*There were significant $(p<0.01)$ differences among the different letters in the same columns

Mediterranean region in Turkey. Previous studies conducted in different agro-climatic regions in Turkey had shown that fruit weight in A. unedo genotypes varied from 0.96 to $13.63 \mathrm{~g}$ (Seker et al., 2004; Celikel et al., 2008). These results also agree with fruit weight estimations performed in other Mediterranean areas (Mulas et al., 1998; Serçe et al., 2010; Molina et al., 2011).

Considering the external fruit colour of the genotypes, 77YLV05 exhibited a significantly higher $L^{*}$ value (46.03), while the lowest values were found in genotypes 77YLV07 and 77YLV08, with 33.11 and 32.06, respectively. A significantly higher $a^{*}$ value (44.71) was recorded in 77YLV02, while the lowest $a^{*}$ values were measured in genotypes 77YLV03 and 77YLV05. The $b^{*}$ value was significantly higher (47.10) in 77YLV05, while the lowest $b^{*}$ values were found in 77YLV07 and 77YLV08, with 31.54 and 29.93, respectively (Tab. 2).

In strawberry tree fruits, oxalic acid, citric acid, malic acid, succinic acid and fumaric acid were determined as major organic acids (Tab. 3). Among them, oxalic acid had the dominant presence in

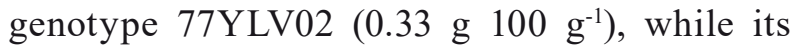

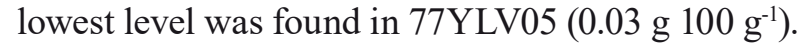
Genotype 77YLV02 also exhibited significantly the

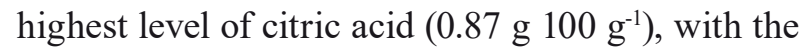

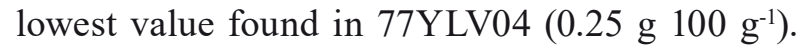
Malic acid content was significantly higher in three genotypes, viz. 77YLV03, 77YLV07 and 77YLV08

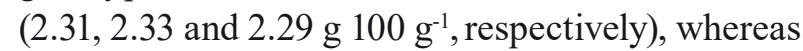
the lowest amounts were in 77YLV01 and 77YLV06. Succinic acid was significantly higher in 77YLV04

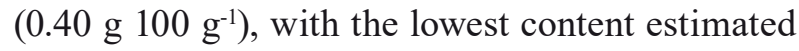

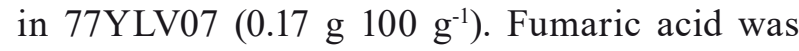
significantly higher in 77YLV06 (0.46 g $\left.100 \mathrm{~g}^{-1}\right)$ among all the genotypes, with the lowest content

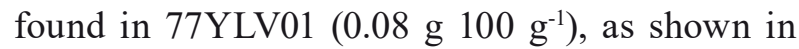
Table 2.

The average amounts of organic acids such as malic acid and citric acid in the fruits analyzed in the present study were higher than those presented by Serçe et al. (2010), which were $0.34{\mathrm{~g} 100 \mathrm{~g}^{-1}}^{-}$

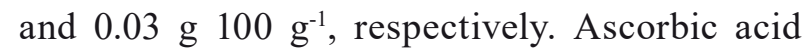
content was also significantly different among the genotypes. Genotypes 77YLV08 and 77YLV02 exhibited the highest levels of ascorbic acid (59.83 $\mathrm{mg} 100 \mathrm{~g}^{-1}$ and $59.38 \mathrm{mg} 100 \mathrm{~g}^{-1}$, respectively). Two genotypes, 77YLV04 and 77YLV07, had

Table 3. Fruit organic acid content of Arbutus unedo genotypes (mean of 2014 and 2015) (g $100 \mathrm{~g}^{-1} \mathrm{fw}$ )

\begin{tabular}{lccccc}
\hline Genotypes & Oxalic acid & Citric acid & Malic acid & Succinic acid & Fumaric acid \\
\hline 77 YLV 01 & $0.18 \pm 0.00 \mathrm{e} *$ & $0.37 \pm 0.00 \mathrm{e}$ & $0.67 \pm 0.03 \mathrm{e}$ & $0.22 \pm 0.01 \mathrm{~d}$ & $0.08 \pm 0.00 \mathrm{f}$ \\
77 YLV 02 & $0.33 \pm 0.01 \mathrm{a}$ & $0.87 \pm 0.02 \mathrm{a}$ & $1.07 \pm 0.06 \mathrm{~d}$ & $0.20 \pm 0.00 \mathrm{~d}$ & $0.16 \pm 0.00 \mathrm{e}$ \\
77 YLV 03 & $0.26 \pm 0.00 \mathrm{~b}$ & $0.58 \pm 0.01 \mathrm{c}$ & $2.31 \pm 0.09 \mathrm{a}$ & $0.36 \pm 0.01 \mathrm{~b}$ & $0.22 \pm 0.00 \mathrm{~d}$ \\
77 YLV 04 & $0.15 \pm 0.00 \mathrm{f}$ & $0.25 \pm 0.00 \mathrm{~g}$ & $1.44 \pm 0.05 \mathrm{c}$ & $0.40 \pm 0.01 \mathrm{a}$ & $0.35 \pm 0.01 \mathrm{~b}$ \\
77 YLV 05 & $0.03 \pm 0.00 \mathrm{~h}$ & $0.36 \pm 0.00 \mathrm{e}$ & $1.65 \pm 0.06 \mathrm{~b}$ & $0.37 \pm 0.02 \mathrm{~b}$ & $0.18 \pm 0.00 \mathrm{e}$ \\
77 YLV 06 & $0.21 \pm 0.00 \mathrm{~d}$ & $0.84 \pm 0.03 \mathrm{~b}$ & $0.74 \pm 0.02 \mathrm{e}$ & $0.29 \pm 0.00 \mathrm{c}$ & $0.46 \pm 0.02 \mathrm{a}$ \\
77 YLV 07 & $0.06 \pm 0.00 \mathrm{~g}$ & $0.30 \pm 0.00 \mathrm{f}$ & $2.33 \pm 0.10 \mathrm{a}$ & $0.17 \pm 0.00 \mathrm{e}$ & $0.26 \pm 0.00 \mathrm{c}$ \\
77 YLV 08 & $0.23 \pm 0.00 \mathrm{c}$ & $0.51 \pm 0.01 \mathrm{~d}$ & $2.29 \pm 0.09 \mathrm{a}$ & $0.21 \pm 0.00 \mathrm{~d}$ & $0.17 \pm 0.00 \mathrm{e}$ \\
\hline
\end{tabular}

*There were significant $(p<0.01)$ differences among the different letters in the same columns 
Table 4. Total antioxidant capacity (TAC), soluble sugars and vitamin C content of Arbutus unedo genotypes (mean of 2014 and 2015)

\begin{tabular}{|c|c|c|c|c|c|}
\hline Genotypes & $\begin{array}{c}\text { Vitamin C } \\
\left(\mathrm{mg} 100 \mathrm{~g}^{-1} \mathrm{fw}\right)\end{array}$ & $\begin{array}{c}\text { Fructose } \\
\left(\mathrm{g} 100 \mathrm{~g}^{-1} \mathrm{fw}\right)\end{array}$ & $\begin{array}{c}\text { Glucose } \\
\left(\mathrm{g} 100 \mathrm{~g}^{-1} \mathrm{fw}\right)\end{array}$ & $\begin{array}{c}\text { Sucrose } \\
\left(\mathrm{g} 100 \mathrm{~g}^{-1} \mathrm{fw}\right)\end{array}$ & $\begin{array}{c}\text { TAC } \\
\left(\mu \mathrm{mol} \mathrm{TE} \mathrm{g}^{-1} \mathrm{fw}\right)\end{array}$ \\
\hline 77 YLV 01 & $58.37 \pm 0.12 \mathrm{ab}^{*}$ & $9.44 \pm 0.28 \mathrm{c}$ & $4.22 \pm 0.09 \mathrm{c}$ & $0.94 \pm 0.01 \mathrm{~b}$ & $17.51 \pm 0.45 \mathrm{e}$ \\
\hline 77 YLV 02 & $59.38 \pm 0.29 \mathrm{a}$ & $11.63 \pm 0.29 \mathrm{a}$ & $6.10 \pm 0.11 \mathrm{a}$ & $1.44 \pm 0.07 \mathrm{a}$ & $22.30 \pm 1.03 \mathrm{c}$ \\
\hline 77 YLV 03 & $58.43 \pm 0.15 \mathrm{ab}$ & $7.13 \pm 0.08 \mathrm{e}$ & $4.20 \pm 0.26 \mathrm{c}$ & $0.35 \pm 0.00 \mathrm{~d}$ & $29.16 \pm 0.61 \mathrm{a}$ \\
\hline 77 YLV 04 & $47.11 \pm 0.11 \mathrm{~d}$ & $8.59 \pm 0.34 \mathrm{~d}$ & $5.37 \pm 0.05 \mathrm{~b}$ & $0.65 \pm 0.02 \mathrm{c}$ & $30.06 \pm 1.68 \mathrm{a}$ \\
\hline 77 YLV 05 & $55.78 \pm 0.21 \mathrm{bc}$ & $6.13 \pm 0.11 \mathrm{f}$ & $3.91 \pm 0.03 \mathrm{~cd}$ & $0.26 \pm 0.00 \mathrm{e}$ & $26.50 \pm 0.97 b$ \\
\hline 77 YLV 06 & $57.09 \pm 0.56 \mathrm{ab}$ & $10.18 \pm 0.11 \mathrm{~b}$ & $5.84 \pm 0.07 \mathrm{a}$ & $0.61 \pm 0.01 \mathrm{c}$ & $19.61 \pm 0.60 \mathrm{~d}$ \\
\hline 77 YLV 07 & $53.73 \pm 1.01 \mathrm{~d}$ & $9.17 \pm 0.50 \mathrm{~cd}$ & $5.10 \pm 0.06 \mathrm{~b}$ & $0.64 \pm 0.03 \mathrm{c}$ & $26.47 \pm 1.07 \mathrm{~b}$ \\
\hline 77 YLV 08 & $59.83 \pm 1.11 \mathrm{a}$ & $7.11 \pm 0.13 \mathrm{e}$ & $3.78 \pm 0.03 \mathrm{~d}$ & $0.17 \pm 0.00 \mathrm{f}$ & $20.37 \pm 0.80 \mathrm{~d}$ \\
\hline
\end{tabular}

*There were significant $(p<0.01)$ differences among the different letters in the same columns

significantly lower amounts of ascorbic acid in their fruits (Table 4). The average vitamin $\mathrm{C}$ levels in our results were higher than in Spanish strawberry tree fruits (6.03 mg $100 \mathrm{~g}^{-1}$ ) (Pallauf et al., 2008), but lower than in Turkish strawberry tree fruits, where they ranged from 98.0 to $280.0 \mathrm{mg} 100 \mathrm{~g} \mathrm{~g}^{-1}$ (Celikel et al., 2008). Vitamin $C$ has also been reported as being present in Arbutus unedo fruits, but found in distinct concentrations: $89 \mathrm{mg} 100 \mathrm{~g}^{-1}$ (Pimpão et al.,

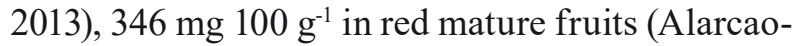
e-Silva et al., 2001), and $182 \mathrm{mg} 100 \mathrm{~g}^{-1}$ (Morales et al., 2013).

We found significant differences $(p<0.05)$ in soluble sugars among the Arbutus unedo genotypes. The results showed that for all the investigated genotypes the major sugar was fructose, which

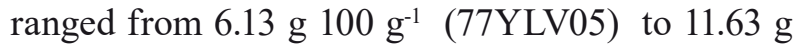
$100 \mathrm{~g}^{-1}$ (77YLV02) (Tab. 3). Glucose and sucrose

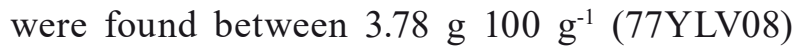

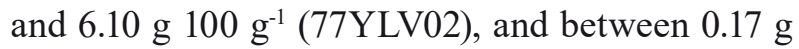

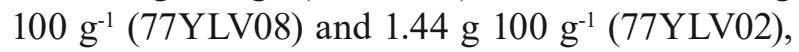
respectively (Tab. 3). The findings indicated a positive correlation between the soluble sugars and fresh weight of the fruits of all the Arbutus unedo genotypes.

Total antioxidant capacity (TAC) based on TEAC was determined for the fruits of all the Arbutus unedo genotypes. The TAC significantly differed among all the genotypes $(p<0.05)$. The fruits of genotypes 77YLV04 and 77YLV03 had significantly the highest TAC values, 30.06 and $29.16 \mu \mathrm{mol} \mathrm{TE} \mathrm{g}^{-1}$, respectively, whereas 77YLV01 had the lowest level of TAC, $17.51 \mu \mathrm{mol} \mathrm{TE} \mathrm{g}{ }^{-1}$ (Tab. 4). The antioxidant capacity of $A$. unedo fruits determined in this study was lower than the amount presented by Serçe et al. (2010) for A. andrachne fruits. Among the determined phenolic acids, gallic acid was found to be the major phenolic acid, which had been reported to be a taste-contributing agent in the fruits (Ayaz et al., 2000). The average concentration of gallic acid was lower than previously reported $(10.7 \mathrm{mg}$ $\mathrm{g}^{-1}$ ) by Ayaz et al. (2000). In the cinnamic group of phenolics, chlorogenic acid was the major phenolic acid. However, chlorogenic acid had previously been reported only in the leaves of the strawberry tree, but not in its fruit (Maleš et al., 2013).

Phenolic acids can be classified into two main groups, the benzoic acid derivatives and the cinnamic acid derivatives. Protocatechuic acid, vanillic acid, gallic acid, and syringic acid belong to the benzoic acid group, while p-coumaric acid, ferulic acid, $o$-coumaric acid and chlorogenic acid are cinnamic acid phenolics. The concentration of protocatechuic acid significantly differed among all the genotypes (Tabs 5 and 6). Fruits of 77YLV06 and 77YLV06 had significantly the highest level $\left(0.6 \mathrm{mg} 100 \mathrm{~g}^{-1}\right)$ of protocatechuic acid, and those of 77 YLV03 had significantly the lowest level $(0.11 \mathrm{mg}$ $\left.100 \mathrm{~g}^{-1}\right)$. Vanillic acid was present in significantly the highest amount in 77YLV02 $(1.17 \mathrm{mg}$ $\left.100 \mathrm{~g}^{-1}\right)$, and in significantly the lowest amount in two genotypes, 77YLV06 and 77YLV08 $(0.1 \mathrm{mg}$ $\left.100 \mathrm{~g}^{-1}\right)$. Gallic acid had the dominant presence in all the genotypes compared to all the other phenolic acids belonging to either the benzoic acid or cinnamic acid group. Gallic acid concentration significantly differed among the genotypes, with the highest level reported in 77YLV07 and the lowest in 77YLV02. The concentration of syringic acid significantly differed among the genotypes, with

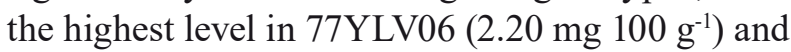
the lowest in two genotypes, 77YLV01 $(0.25 \mathrm{mg}$ $\left.100 \mathrm{~g}^{-1}\right)$ and 77YLV02 $\left(0.31 \mathrm{mg}^{\left.100 \mathrm{~g}^{-1}\right) . P \text {-coumaric }}\right.$ acid was present in significant amounts in only one genotype, 77YLV04, with the lowest amounts recorded in three genotypes: 77YLV02, 77YLV07 
Table 5. Fruit phenolic matter content of Arbutus unedo genotypes (mean of 2014 and 2015) (mg $\left.100 \mathrm{~g}^{-1} \mathrm{fw}\right)-\mathrm{part} 1$

\begin{tabular}{lccccccc}
\hline Genotypes & $\begin{array}{c}\text { Protocatechuic } \\
\text { acid }\end{array}$ & $\begin{array}{c}\text { Vanillic } \\
\text { acid }\end{array}$ & $\begin{array}{c}\text { Ellagic } \\
\text { acid }\end{array}$ & Rutin & Quercetin & $\begin{array}{c}\text { Gallic } \\
\text { acid }\end{array}$ & Catechin \\
\hline 77 YLV 01 & $0.60 \pm 0.01 \mathrm{a}^{*}$ & $0.64 \pm 0.01 \mathrm{c}$ & $1.70 \pm 0.16 \mathrm{ab}$ & $0.24 \pm 0.00 \mathrm{e}$ & $0.12 \pm 0.00 \mathrm{~d}$ & $2.52 \pm 0.11 \mathrm{f}$ & $1.16 \pm 0.06 \mathrm{f}$ \\
77 YLV 02 & $0.50 \pm 0.01 \mathrm{~b}$ & $1.17 \pm 0.02 \mathrm{a}$ & $1.71 \pm 0.13 \mathrm{ab}$ & $0.43 \pm 0.00 \mathrm{~d}$ & $0.19 \pm 0.00 \mathrm{c}$ & $1.62 \pm 0.07 \mathrm{~g}$ & $2.51 \pm 0.13 \mathrm{~d}$ \\
77 YLV 03 & $0.11 \pm 0.00 \mathrm{e}$ & $0.69 \pm 0.03 \mathrm{~b}$ & $1.41 \pm 0.11 \mathrm{ab}$ & $0.64 \pm 0.01 \mathrm{c}$ & $0.19 \pm 0.00 \mathrm{c}$ & $3.35 \pm 0.15 \mathrm{e}$ & $2.10 \pm 0.09 \mathrm{e}$ \\
77 YLV 04 & $0.19 \pm 0.00 \mathrm{c}$ & $0.47 \pm 0.00 \mathrm{~d}$ & $1.26 \pm 0.12 \mathrm{ab}$ & $0.18 \pm 0.00 \mathrm{f}$ & $0.23 \pm 0.00 \mathrm{~b}$ & $3.19 \pm 0.12 \mathrm{e}$ & $2.47 \pm 0.02 \mathrm{~d}$ \\
77 YLV 05 & $0.16 \pm 0.00 \mathrm{~cd}$ & $0.17 \pm 0.00 \mathrm{e}$ & $1.11 \pm 0.09 \mathrm{~b}$ & $0.30 \pm 0.00 \mathrm{e}$ & $0.31 \pm 0.01 \mathrm{a}$ & $4.21 \pm 0.21 \mathrm{~d}$ & $4.38 \pm 0.15 \mathrm{c}$ \\
77 YLV 06 & $0.61 \pm 0.02 \mathrm{a}$ & $0.10 \pm 0.00 \mathrm{f}$ & $1.92 \pm 0.13 \mathrm{ab}$ & $0.15 \pm 0.00 \mathrm{f}$ & $0.21 \pm 0.00 \mathrm{c}$ & $6.62 \pm 0.28 \mathrm{~b}$ & $4.31 \pm 0.13 \mathrm{c}$ \\
77 YLV 07 & $0.19 \pm 0.00 \mathrm{c}$ & $0.18 \pm 0.00 \mathrm{e}$ & $2.13 \pm 0.27 \mathrm{a}$ & $0.84 \pm 0.01 \mathrm{~b}$ & $0.31 \pm 0.00 \mathrm{a}$ & $7.29 \pm 0.41 \mathrm{a}$ & $5.75 \pm 0.25 \mathrm{a}$ \\
77 YLV 08 & $0.15 \pm 0.00 \mathrm{~d}$ & $0.09 \pm 0.00 \mathrm{f}$ & $1.13 \pm 0.08 \mathrm{~b}$ & $0.95 \pm 0.02 \mathrm{a}$ & $0.25 \pm 0.00 \mathrm{~b}$ & $5.09 \pm 0.16 \mathrm{c}$ & $4.70 \pm 0.17 \mathrm{~b}$ \\
\hline
\end{tabular}

*There were significant $(p<0.01)$ differences among the different letters in the same columns

and 77YLV08. Ferulic acid and $o$-coumaric acid were present in minute fractions in all the genotypes. Significantly the highest amount of ferulic acid

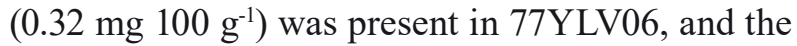

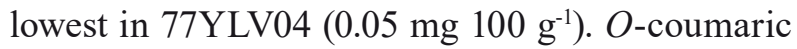
acid was in undetectable amounts in four genotypes: 77YLV01, 77YLV02, 77YLV06 and 77YLV08, while significantly the highest content $(0.07 \mathrm{mg}$ $100 \mathrm{~g}^{-1}$ ) was found in 77YLV04, and the lowest amount was found in 77YLV07 (0.05 mg $\left.100 \mathrm{~g}^{-1}\right)$. Among the cinnamic acid group of phenolic acids, chlorogenic acid was in significantly the highest amounts in all the genotypes. Significantly the highest content was found in 77YLV05 $(3.14 \mathrm{mg}$ $\left.100 \mathrm{~g}^{-1}\right)$, and the lowest in two genotypes: 77YLV07 $\left(1.33 \mathrm{mg} 100 \mathrm{~g}^{-1}\right)$ and 77YLV08 (1.23 mg $\left.100 \mathrm{~g}^{-1}\right)$ (Tab. 5 - part 1 and part 2).

Miscellaneous phenolics were also determined by the HPLC method. Those were ellagic acid, rutin, quercetin, catechin and phloridzin. Therefore, to explore this antioxidant activity, phenolic acids, tannins and the chalcone content were determined. The tannin derivatives, ellagic acid and catechin, were determined, and, compared to ellagic acid, catechin was found in higher amounts in the fruits of all the genotypes. Genotype 77YLV07 exhibited the highest amount of catechin (5.75 mg $\left.100 \mathrm{~g} \mathrm{~g}^{-1}\right)$, while 77YLV01 had the lowest (1.16 mg $\left.100 \mathrm{~g}^{-1}\right)$. Genotype 77YLV07 also showed the highest ellagic acid content ( $\left.2.13 \mathrm{mg} 100 \mathrm{~g}^{-1}\right)$, while the lowest content, 1.11 and $1.13 \mathrm{mg} 100 \mathrm{~g} \mathrm{~g}^{-1}$, was found in two genotypes, 77YLV05 and 77YLV08, respectively. Rutin and quercetin, which are flavonoids, were present in lower amounts in the fruits of all the genotypes. However, rutin was found in relatively higher amounts compared to quercetin. Genotype 77YLV08 exhibited significantly the highest amount of rutin $\left(0.95 \mathrm{mg} 100 \mathrm{~g} \mathrm{~g}^{-1}\right)$, with the lowest

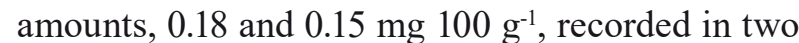
genotypes, 77YLV04 and 77YLV06, respectively. Quercetin was present in fractional amounts, and genotypes 77YLV05 and 77YLV07 contained the highest amount $\left(0.31 \mathrm{mg} 100 \mathrm{~g}^{-1}\right)$, whereas the lowest amount was recorded in 77YLV01 $(0.12 \mathrm{mg}$ $\left.100 \mathrm{~g}^{-1}\right)$. Phloridzin, which is a chalcone derivative, was present in significant amounts among the genotypes. 77YLV05 had the highest amount $\left(0.83 \mathrm{mg} 100 \mathrm{~g} \mathrm{~g}^{-1}\right)$, and the genotypes 77YLV07 and 77 YLV08 had the lowest amounts $\left(0.12 \mathrm{mg} 100 \mathrm{~g}^{-1}\right.$

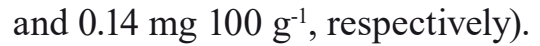

Table 5. Fruit phenolic matter content of Arbutus unedo genotypes (mean of 2014 and 2015) (mg $\left.100 \mathrm{~g}^{-1} \mathrm{fw}\right)-\mathrm{part} 2$

\begin{tabular}{|c|c|c|c|c|c|c|}
\hline Genotypes & $\begin{array}{l}\text { Syringic } \\
\text { acid }\end{array}$ & $\begin{array}{l}p \text {-Coumaric } \\
\text { acid }\end{array}$ & $\begin{array}{l}\text { Ferulic } \\
\text { acid }\end{array}$ & $\begin{array}{l}o \text {-Coumaric } \\
\text { acid }\end{array}$ & $\begin{array}{l}\text { Chlorogenic } \\
\text { acid }\end{array}$ & Phloridzin \\
\hline 77 YLV 01 & $0.25 \pm 0.00 \mathrm{~g}^{*}$ & $0.46 \pm 0.02 \mathrm{~b}$ & $0.09 \pm 0.00 \mathrm{de}$ & n.d. & $2.17 \pm 0.06 \mathrm{~b}$ & $0.32 \pm 0.01 \mathrm{c}$ \\
\hline 77 YLV 02 & $0.31 \pm 0.01 \mathrm{~g}$ & $0.09 \pm 0.00 \mathrm{~d}$ & $0.10 \pm 0.00 \mathrm{~cd}$ & n.d. & $2.25 \pm 0.03 \mathrm{~b}$ & $0.30 \pm 0.00 \mathrm{c}$ \\
\hline 77 YLV 03 & $0.63 \pm 0.02 \mathrm{f}$ & $0.30 \pm 0.00 \mathrm{c}$ & $0.13 \pm 0.00 \mathrm{bcd}$ & $0.06 \pm 0.00 \mathrm{~b}$ & $2.04 \pm 0.01 \mathrm{~b}$ & $0.71 \pm 0.03 b$ \\
\hline 77 YLV 04 & $1.20 \pm 0.02 \mathrm{c}$ & $1.07 \pm 0.12 \mathrm{a}$ & $0.05 \pm 0.00 \mathrm{e}$ & $0.07 \pm 0.00 \mathrm{a}$ & $2.71 \pm 0.09 \mathrm{ab}$ & $0.74 \pm 0.03 b$ \\
\hline 77 YLV 05 & $1.33 \pm 0.05 \mathrm{~b}$ & $0.43 \pm 0.00 \mathrm{~b}$ & $0.16 \pm 0.00 \mathrm{~b}$ & $0.06 \pm 0.00 \mathrm{~b}$ & $3.14 \pm 0.11 \mathrm{a}$ & $0.83 \pm 0.09 a$ \\
\hline 77 YLV 06 & $2.20 \pm 0.09 \mathrm{a}$ & $0.21 \pm 0.00 \mathrm{~cd}$ & $0.32 \pm 0.01 \mathrm{a}$ & n.d. & $2.29 \pm 0.03 \mathrm{~b}$ & $0.25 \pm 0.00 \mathrm{c}$ \\
\hline 77 YLV 07 & $0.81 \pm 0.02 \mathrm{e}$ & $0.11 \pm 0.00 \mathrm{~d}$ & $0.13 \pm 0.00 \mathrm{bcd}$ & $0.05 \pm 0.00 \mathrm{bc}$ & $1.33 \pm 0.00 \mathrm{c}$ & $0.12 \pm 0.00 \mathrm{~d}$ \\
\hline 77 YLV 08 & $1.00 \pm 0.03 \mathrm{~d}$ & $0.18 \pm 0.00 \mathrm{~d}$ & $0.15 \pm 0.00 \mathrm{~b}$ & n.d. & $1.23 \pm 0.07 \mathrm{c}$ & $0.14 \pm 0.00 \mathrm{~d}$ \\
\hline
\end{tabular}

*There were significant $(p<0.01)$ differences among the different letters in the same columns; n.d.: not determined 


\section{CONCLUSIONS}

1. We investigated the anticancer phenolic compounds, pomological characteristics of strawberry tree fruits and their soluble sugars, concentrations of organic acids, vitamin $\mathrm{C}$ and total antioxidant activity. Pomologic and biochemical properties were statistically significantly different among the genotypes $(p<0.05)$.

2. More intensive studies is needed for the identification of genes responsible for biochemical properties.

\section{AUTHOR CONTRIBUTIONS}

M.G., S.E., I.C, E.O., M.S., M.N. and R.B.A. - contributed equally to this work.

\section{CONFLICT OF INTEREST}

Authors declare no conflict of interest.

\section{REFERENCES}

Alarcao-E-Silva M., Leitão A., Azinheira H., Leitão M., 2001. The arbutus berry: Studies on its color and chemical characteristics at two mature stages. J. Food Compos. Anal. 14, 27-35.

Alp S., Ercisli S., Dogan H., Temim E., Leto A., ZiaUl-Haq M., Hadziabulic A., Aladag H., 2016. Chemical composition and antioxidant activity Ziziphora clinopodioides ecotypes from Turkey. Rom. Biotechnol. Lett. 21(2), 11298-11303.

Ayaz F.A., Kucukislamoglu M., Reunanen M., 2000. Sugar, non-volatile and phenolic acids composition of strawberry tree (Arbutus unedo L. var. ellipsoidea) fruits. J. Food Compos. Anal. 13, 171-177.

Barros L., Carvalho A.M., Morais J.S., Ferreira I.C., 2010. Strawberry-tree, blackthorn and rose fruits: Detailed characterisation in nutrients and phytochemicals with antioxidant properties. Food Chem. 120, 247-254.

Bevilacqua A.E., Califano A.N., 1989. Determination of organic acids in dairy products by high performance liquid chromatography. J. Food Sci. 54, 1076-1079.

Blanco E., Casado M.A., Costa M., Escribano R., García M., GÉnova M., et AL., 1997. Los Bosques Ibéricos. Una Interpretación Geobotánica, Planeta, Madrid.

Bonet M.À., Vallès J., 2002. Use of non-crop food vascular plants in Montseny biosphere reserve (Catalonia, Iberian Peninsula). Int. J. Food Sci. Nutr. 53, 225-248.

Caliskan O., Kazim G., Serce S., Toplu C., Kamiloglu O., Sengul M., Ercisli S., 2012. Phytochemical characterization of several howthorn (Crataegus spp) species sampled from the Eastern Mediterranean region of Turkey. Pharmacogn. Mag. 8, 16-21.

Canan I., GündoĞdu M., Seday U., Oluk C.A., Karaşahin Z., ERoĞLu E.Ç., YaZici E., Ünlü M., 2016. Determination of antioxidant, total phenolic, total carotenoid, lycopene, ascorbic acid, and sugar contents of Citrus species and mandarin hybrids. Turk. J. Agric. For. 40, 894-899.

Carvalho A.M., 2010. Plantas y sabiduría popular del Parque Natural de Montesinho: un estudio etnobotánico en Portugal. Editorial CSIC-CSIC Press.

Celikel G., Demirsoy L., Demirsoy H., 2008. The strawberry tree (Arbutus unedo L.) selection in Turkey. Sci. Hortic. 118, 115-119.

Cemeroglu B., 2007. G1da analizleri. G1da Tek. Der. Yay. 34, 168-171.

Dogan H., Ercisli S., Temim E., Hadziabulic A., Tosun M., Yilmaz So., Zia-Ul-HaQ M., 2014. Diversity of chemical content and biological activity in flower buds of a wide number of wild grown caper (Capparis ovate Desf.) genotypes from Turkey. C. R. Acad. Bulg. Sci. 67(11), 1593-1600.

ERCISLI S, 2004. A short review of the fruit germplasm resources of Turkey. Gen. Res. Crop. Evol. 51, 419435.

Ercisli S., Sengul M., Yildiz H., Sener D., Duraliua B., Voca S., Purgar D.D., 2012. Phytochemical and antioxidant characteristics of medlar fruits (Mespilus germanica L.). J. Appl. Bot. Food Qual. 85, 86-90.

Garcia-Alonso M., De Pascual-Teresa S., SantosBuelga C., Rivas-Gonzalo J.C., 2004. Evaluation of the antioxidant properties of fruits. Food Chem. $84,13-18$.

Hadjichambis A.C., Paraskeva-Hadjichambi D., Della A., Giusti M.E., De Pasquale C., Lenzarini C., ET AL., 2008. Wild and semi-domesticated food plant consumption in seven circum-Mediterranean areas. Int. J. Food Sci. Nutr. 59, 383-414.

Kamiloglu O., Ercisli S., Sengul M., Toplu C., Serce S., 2009. Total phenolics and antioxidant activity of jujube (Zizyphus jujube Mill.) genotypes selected from Turkey. Afr. J. Biotechnol. 8, 303-307.

MALEŠ Ž., ŠArić D., BoJIĆ M., 2013. Quantitative determination of flavonoids and chlorogenic acid in the leaves of Arbutus unedo L. using thin layer chromatography. J. Anal. Methods Chem. 2013, 385473.

McGuire R.G., 1992. Reporting of objective color measurements. HortScience 27, 1254-1255.

Melgarejo P., Salazar D.M., Artes F., 2000. Organic acids and sugars composition of harvested pomegranate fruits. Eur. Food Res. Technol. 211, 185 190.

Mikulic-Petkovsek M., Samoticha J., Eler K., Stampar F., Veberic, R., 2015. Traditional elderflower beverages: a rich source of phenolic compounds with high antioxidant activity. J. Agric. Food Chem. 63(5), 1477-1487. 
Mikulic-Petkovsek M., Schmitzer V., Slatnar A., Stampar F., Veberic R., 2012. Composition of sugars, organic acids, and total phenolics in 25 wild or cultivated berry species. J. Food Sci. 77(10), C1064-C1070.

Molina M., Pardo-De-Santayana M., Aceituno L., Morales R., TARdío J., 2011. Fruit production of strawberry tree (Arbutus unedo L.) in two Spanish forests. Forestry 84, 419-429.

Moll M., 2005. Les plantes a Menorca: noms i usos. Maó, Spain: Institut Menorquí d'Estudis.

Morales P., Ferreira I.C.F.R., Carvalho A.M., Fernández-Ruiz V., SÁnChez-Mata M.C., CÂmara M., Morales R., TARdio J., 2013. Wild edible fruits as a potential source of phytochemicals with capacity to inhibit lipid peroxidation. Eur. J. Lipid Sci. Technol. 115, 176-185.

Mulas M., Cani M., Brigaglia N., Deidda P., 1998. Selezione varietale da popolazioni spontanee per la coltivazione di mirto e coberzzolo in Sardegna. Rivista di Frutticoltura 3, 45-50.

Ozgen M., Reese R.N., Tulio A.Z., Scheerens J.C., Miller A.R., 2006. Modified 2.2- azino-bis-3ethylbenzothiazoline-6-sulfonic acid (ABTS) method to measure antioxidant capacity of selected small fruits and a comparison to ferric reducing antioxidant power (FRAP) and 2.2-diphenyl-1-picrylhdrazyl (DPPH) methods. J. Agric. Food Chem. 54, 1151-1157.

Pallauf K., Rivas-Gonzalo J.C., Del Castillo M., Cano M.P., De Pascual-Teresa S., 2008. Characterization of the antioxidant composition of strawberry tree (Arbutus unedo L.) fruits. J. Food Compos. Anal. 21, 273-281.

Parada M., Selga A., Bonet M., Vallès J., 2002. Etnobotànica de les terres gironines, natura i cultura popular a la plana interior de l'Alt Empordà ia les Guilleries. Diputació de Girona, Girona, Spain.

Pimpão R.C., Dew T., Oliveira P.B., Williamson G., Ferreira R.B., Santos C.N., 2013 Analysis of phenolic compounds in Portuguese wild and commercial berries after multienzyme hydrolysis. J. Agric. Food Chem. 61, 4053-4062.
Rodriguez-Delgado M.A., Malovana S., Perez J.P., Borges T., Garcia-Montelongo F.J., 2001. Separation of phenolic compounds by highperformance liquid chromatography with absorbance and fluorimetric detection. J. Chromatogr. 912, 249257.

Ruiz-Rodríguez B.M., Morales P., FernándezRuiz V., Sánchez-Mata M.C., Cámara M., DíezMarqués C., Pardo-De-Santayana M., Molina M., TARDío J., 2011. Valorization of wild strawberrytree fruits (Arbutus unedo L.) through nutritional assessment and natural production data. Food Res. Int. 44, 1244-1253.

Seker M., Yucel Z., Nurdan E., 2004. Canakkale yoresi dogal florasinda bulunan Kocayemis(Arbutus unedo L.) populasyonunun morfolojik ve pomolojik ozelliklerinin incelenmesi. AU. Ziraat Fak. Tar. Bili. Der. 10, 422-427.

Serçe S., Özgen M., Torun A.A., Ercişli S., 2010. Chemical composition, antioxidant activities and total phenolic content of Arbutus andrachne L. (Fam. Ericaceae) (the Greek strawberry tree) fruits from Turkey. J. Food Compos. Anal. 23, 619-623.

Takrouni M.M., Boussaid M., 2010. Genetic diversity and population's structure in Tunisian strawberry tree (Arbutus unedo L.). Sci. Hortic. 126, 330-337.

Tosun M., Ercisli S., Karlidag H., Sengul M., 2009. Characterization of red raspberry (Rubus idaeus L.) genotypes for their physicochemical properties. J. Food Sci. 74, C575-C579.

Veberic R., Slatnar A., Bizjak J., Stampar F., Mikulic-Petkovsek M., 2015. Anthocyanin composition of different wild and cultivated berry species. LWT - Food Sci. Technol. 60, 509-517.

Zorenc Z., Veberic R., Stampar F., Koron D., Mikulic-Petkovsek M., 2016. Changes in berry quality of northern highbush blueberry (Vaccinium corymbosum L.) during the harvest season. Turk J. Agric. For. 40, 855-868.

Received October 31, 2017; accepted February 5, 2018 